\title{
EVALUASI PEMBERIAN UNSUR HARA BESI PADA KANDUNGAN ASAM AMINO DAN MINERAL DALAM BIJI JAGUNG
}

\author{
Deden Saprudin ${ }^{1, *}$, Citra Ajeng Palupi ${ }^{1}$, Eti Rohaeti $^{1}$ \\ ${ }^{1)}$ Departemen Kimia FMIPA IPB, Bandung \\ *dsp@apps.ipb.ac.id
}

Received 31 January 2019

Accepted 28 June 2019

\begin{abstract}
Abstrak
Evaluasi pemberian pupuk nanomagnetit $\left(\mathrm{Fe}_{3} \mathrm{O}_{4}\right) 25 \mathrm{ppm}$ dan pupuk komersial Fe-kelat 250 ppm terhadap kandungan nutrisi dalam biji jagung seperti kandungan proksimat, asam amino, serta mineral telah dilakukan. Asam amino ditentukan menggunakan kromatografi cair kinerja tinggi (KCKT) dan mineral ditentukan menggunakan spektrofotometri serapan atom (SSA). Pengolahan data melalui uji anova satu arah untuk membandingkan kedua jenis perlakuan. Perlakuan Fe-kelat 250 ppm dapat meningkatkan kandungan total asam amino $32 \%$ dan total mineral $86 \%$. Begitupun perlakuan nanomagnetit $25 \mathrm{ppm}$ juga terbukti meningkatkan kandungan total asam amino sebesar $18 \%$ dan total mineral $29 \%$ pada biji jagung secara signifikan jika dibandingkan dengan kontrol berdasarkan uji anova.
\end{abstract}

Katakunci: Asam amino, besi, nanomagnetit, dan mineral

\begin{abstract}
Evaluation of the use of $25 \mathrm{ppm}$ nanomagnetite $\left(\mathrm{Fe}_{3} \mathrm{O}_{4}\right)$ and $250 \mathrm{ppm}$ Fe chelate as fertilizer on nutrient content in corn seeds such as proximate content, amino acids, and minerals was carried out. Amino acids were determined using high performance liquid chromatography (HPLC) and minerals determined using atomic absorption spectrophotometry (AAS). Processing data through one-way ANOVA test to compare the two types of treatment. The treatment of Fe chelate $250 \mathrm{ppm}$ can increase the total amino acid content by $32 \%$ and total minerals by $86 \%$. Likewise, the $25 \mathrm{ppm}$ nanomagnetite treatment was also shown to increase significantly the total amino acid content by $18 \%$ and the total mineral by $29 \%$ in corn seeds compared with the control, based on the ANOVA test.
\end{abstract}

Keywords: Amino acid, iron, nanomagnetite, and mineral

\section{Pendahuluan}

Produktivitas jagung yang masih rendah belum mampu untuk memenuhi kebutuhan jagung dalam negeri sehingga perlu dilakukan impor (BPS 2015). Hal ini menunjukkan bahwa jagung berpotensi untuk dikembangkan di Indonesia, mengingat jagung memiliki kandungan nutrisi yang baik. Menurut United State Department of Agricultural (2016), kandungan makro pada biji jagung mentah per $100 \mathrm{~g}$, yaitu karbohidrat $18.70 \mathrm{~g}$, protein $3.27 \mathrm{~g}$, lemak $1.35 \mathrm{~g}$, dan serat sebesar 2 g. Kandungan mineral per $100 \mathrm{~g}$ antara lain, kalium $270 \mathrm{mg}$, natrium $15 \mathrm{mg}$, kalsium $2 \mathrm{mg}$, tembaga $0.054 \mathrm{~g}$, magnesium $37 \mathrm{mg}$, mangan $0.163 \mathrm{mg}$, zink $0.46 \mathrm{mg}$, dan besi $0.52 \mathrm{mg}$.

Besi merupakan unsur hara esensial karena menjadi bagian dari enzim-enzim tertentu dan bagian dari protein yang terlibat dalam transfer elektron (reaksi redoks) sebagai pembawa elektron pada fase terang fotosintesis dan respirasi. Besi teroksidasi secara reversibel dari $\mathrm{Fe}^{2+} \mathrm{ke}$ 
$\mathrm{Fe}^{3+}$ selama transfer elektron. Besi memengaruhi tingkat klorofil karena $\mathrm{Fe}$ dibutuhkan dalam pembentukan ultrastruktur kloroplas (Bozorgi 2012). Jika tanaman defisiensi besi maka akan menyebabkan klorosis pada daun (Oh et al. 1996).

Pemupukan merupakan salah satu cara untuk menyediakan unsur hara yang dibutuhkan oleh tanaman, serta dapat meningkatkan kesehatan tanaman dan menekan perkembangan penyakit (Prahasta 2009). Nanomagnetit adalah pupuk berukuran nano yang diapikasikan pada tanaman jagung. Studi terkait telah menyatakan bahwa nanomagnetit $\left(\mathrm{Fe}_{3} \mathrm{O}_{4}\right)$ meningkatkan tinggi tanaman, luas daun, berat kering tanaman pir, dan juga meningkatkan kadar besi dan klorofil pada daun tanaman ( El-Nasr et al. 2015).

Penelitian yang telah dilakukan oleh Randabunga (2018) adalah menambahkan nanomagnetit $\left(\mathrm{Fe}_{3} \mathrm{O}_{4}\right)$ serta melihat pengaruhnya terhadap pertumbuhan tanaman jagung yang dibandingkan dengan penggunaan pupuk komersial Fekelat ethylene diamine- $N, N$ bis (2 hidroxy phenil acetic acid) (Fe EDDHA). Kelat ini digunakan untuk perbandingan secara ilmiah. Fe-kelat merupakan kelompok fenolik yang sangat efektif, terutama di tanah berkapur, namun harganya mahal (Abadía et al. 2011). Hasilnya menunjukan bahwa penambahan nanomagnetit $25 \mathrm{ppm}$ meningkatkan pertumbuhan tanaman jagung serta bobot basah dan bobot kering hasil panen jagung secara signifikan. Dengan penambahan pupuk komersial $\mathrm{Fe}$ kelat hasil yang serupa pun didapatkan, namun diperlukan konsentrasi Fe-kelat yang lebih tinggi yaitu sebesar $250 \mathrm{ppm}$. Penelitian ini dilakukan untuk mengetahui pengaruh penambahan nanomagnetit pada konsentrasi 25 ppm dibandingkan dengan penambahan Fe-kelat pada konsentrasi 250 ppm terhadap kontrol pada kandungan proksimat, asam amino, serta mineral pada biji jagung.

\section{Metode Penelitian}

\section{Alat dan bahan}

Alat-alat yang digunakan antara lain alat-alat kaca, cawan porselin, tanur, blender (merk Panasonic), pembakar gas, piringan pemanas, desikator, alat destruksi protein, labu Kjeldahl, alat destilasi Kjeldahl, seperangkat alat soklet dan alat refluks, pendingin tegak, pompa vakum, penguap putar, tabung ulir, tube, saringan $0.45 \mathrm{~nm}$, mikrovial, vial, vorteks, kromatografi cair kinerja tinggi (Water $U P L C$ ), dan spektrofotometer serapan atom (Shimadzu AA-7000).

Bahan-bahan yang digunakan dalam penelitian ini, yaitu buah jagung tanpa perlakuan sebagai kontrol, jagung yang telah diberi perlakuan besi Fe-kelat 250 ppm, dan jagung yang telah diberi perlakuan nanomagnetit $25 \mathrm{ppm}, \mathrm{H}_{2} \mathrm{SO}_{4}$, $\mathrm{K}_{2} \mathrm{SO}_{4}, \mathrm{CuSO}_{4}, \mathrm{NaOH} 40 \%$, asam borat $4 \%$, indikator merah metil, $\mathrm{HCl} 0.1 \mathrm{M}, \mathrm{n}$ heksana pa, $\mathrm{H}_{2} \mathrm{SO}_{4} 1.25 \%, \mathrm{NaOH} 1.25 \%$, $\mathrm{HCl} 6 \mathrm{~N}$, standar alpha amino butyric acid (AABA), AccQ-Flour borat, reagen flour A, $\mathrm{ddH}_{2} \mathrm{O}, \mathrm{NaCl}, \mathrm{KCl}, \mathrm{ZnSO}_{4} .7 \mathrm{H}_{2} \mathrm{O}$, $\mathrm{CaSO}_{4} \cdot 2 \mathrm{H}_{2} \mathrm{O}, \mathrm{MnSO}_{4} \cdot \mathrm{H}_{2} \mathrm{O}, \mathrm{CuSO}_{4} \cdot \mathrm{H}_{2} \mathrm{O}$, $\mathrm{MgCl}_{2} .5 \mathrm{H}_{2} \mathrm{O}$, dan $\mathrm{FeCl}_{3} .6 \mathrm{H}_{2} \mathrm{O}$.

\section{Preparasi Contoh}

Sampel jagung dikeringkan dalam oven pada suhu $\pm 40^{\circ} \mathrm{C}$, lalu dipisahkan dari tongkolnya. Butiran biji jagung dikeringkan kembali pada suhu tersebut hingga kering agar awet dan tidak berjamur. Sampel sebanyak $50 \mathrm{~g}$ kemudian dihaluskan dengan blender (merk Panasonic) pada tingkat 1 selama 2 menit, dinaikkan ketingkat 2 selama 2 menit, dan tingkat 3 selama 1 menit hingga menjadi serbuk. Contoh serbuk biji jagung digunakan untuk penentuan kadar air, kadar abu, kadar protein, kadar lemak, kadar karbohidrat, kadar serat kasar, kadar asam amino, dan kadar mineral.

Penentuan Kadar Air (AOAC 2012)

Cawan porselin kosong dikeringkan dalam oven bersuhu $103^{\circ}-104^{\circ} \mathrm{C}$ selama 
30 menit, kemudian didinginkan dalam desikator selama 30 menit dan ditimbang bobotnya. Sebanyak $5 \mathrm{~g}$ sampel ditimbang ke dalam cawan yang telah diketahui bobotnya. Cawan berisi sampel dikeringkan dalam oven bersuhu $103^{\circ}$ $104^{\circ} \mathrm{C}$ selama 3 jam. Cawan didinginkan dalam desikator selama 30 menit dan ditimbang bobotnya. Pengeringan dan penimbangan dilakukan kembali masingmasing selama 1 jam hingga diperoleh bobot konstan. Penentuan kadar air dilakukan 3 kali ulangan.

\section{Penentuan Kadar Abu (AOAC 2005)}

Cawan porselin dikeringkan dalam tanur selama 30 menit pada suhu $600^{\circ} \mathrm{C}$, kemudian didinginkan dalam desikator selama 30 menit lalu ditimbang bobotnya. Sebanyak 2 g sampel ditimbang ke dalam cawan, lalu cawan dan isinya dibakar hingga tidak berasap, kemudian diabukan dalam tanur selama 2 jam pada suhu $600^{\circ} \mathrm{C}$ hingga abu berwarna putih. Setelah didinginkan dalam desikator, cawan dan abu kemudian ditimbang bobotnya. Cawan dimasukkan dalam desikator dan ditimbang kembali hingga diperoleh bobot konstan. Penentuan kadar abu dilakukan 3 kali ulangan.

\section{Penetapan Nitrogen dan Protein Kasar (AOAC 2005)}

Penetapan nitrogen dilakukan dengan menggunakan metode Kjeldahl untuk menentukan $\% \mathrm{~N}$ total pada biji jagung. Sebanyak $0.1 \mathrm{~g}$ contoh ditimbang dalam labu destruksi, lalu ditambahkan $12 \mathrm{ml}$ $\mathrm{H}_{2} \mathrm{SO}_{4}$ pekat dan 2 tablet katalis (3.5 g $\mathrm{K}_{2} \mathrm{SO}_{4}$ dan $0.4 \quad \mathrm{~g} \quad \mathrm{CuSO}_{4}$ pertablet). Campuran kemudian didestruksi selama 50 menit, selanjutnya larutan hasil destruksi ini ditempatkan pada alat destilasi, lalu $\mathrm{NaOH} 40 \%$ ditambahkan hingga volemenya menjadi $50 \mathrm{~mL}$, kemudian didestilasi. Destilat yang didapat kemudian ditampung di dalam Erlenmeyer $500 \mathrm{~mL}$ yang berisi $30 \mathrm{~mL}$ asam borat $4 \%$ dan indikator metil merah, selanjutnya campuran dalam Erlenmeyer tersebut dititrasi dengan $\mathrm{HCl} 0.1 \mathrm{M}$. Titik akhir titrasi ditandai dengan terjadinya perubahan warna kuning menjadi merah muda seulas.

\section{Penetapan Kadar Lemak Kasar (AOAC 2005)}

Sebanyak 3 g sampel ditimbang dan dibungkus dengan kertas saring menyerupai selongsong dan ujungnya disumbat dengan kapas. Labu bulat dan batu didih disiapkan. Labu dan batu didih dipanaskan dalam oven selama 30 menit pada suhu $110^{\circ} \mathrm{C}$ dan dimasukkan ke dalam desikator, lalu ditimbang. Seperangkat alat soklet disiapkan, lalu selongsong sampel dimasukkan ke dalam soklet dan labu bulat yang telah diketahui bobotnya dipasang. Setelah itu, pelarut nheksana dimasukkan hingga sampel terendam. Ekstaksi dilakukan 5-6 siklus atau sekitar 6 jam pada suhu $102{ }^{\circ} \mathrm{C}$. Kemudian, selongsong sampel diangkat dan dididihkan kembali selama 40 menit, lalu pelarut diambil dari radas soklet. Labu yang berisi lemak kemudian dipanaskan selama 30 menit pada suhu $110^{\circ} \mathrm{C}$ untuk menghilangkan pelarut. Labu dimasukkan dalam desikator selama 30 menit dan ditimbang. Labu ditimbang kembali hingga diperoleh bobot konstan. Ekstraksi dilakukan 3 kali ulangan.

\section{Penetapan Kadar Serat (AOAC 2005)}

Sebanyak 2 g contoh ditimbang $\left(\mathrm{W}_{1}\right)$, lalu dimasukkan ke dalam labu bulat dan ditambahkan batu didih, kemudian ditambahkan $200 \mathrm{~mL} \mathrm{H}_{2} \mathrm{SO}_{4} 1.25 \%$ dan direfluks selama 30 menit. Setelah itu disaring vakum yang telah dicuci dengan air panas, kemudian dicuci kembali menggunakan $40 \mathrm{~mL}$ air panas. Residu yang telah didapatkan kemudian direfluks kembali menggunakan $200 \mathrm{~mL} \mathrm{NaOH}$ $1.25 \%$ selama 30 menit, lalu disaring vakum dan dicuci menggunakan $\mathrm{H}_{2} \mathrm{SO}_{4}$ $1.25 \%$ panas. Residu kemudian dimasukkan dalam oven selama 2 jam pada suhu $130^{\circ} \mathrm{C}$. Setelah itu didinginkan dalam desikator dan ditimbang $\left(\mathrm{W}_{2}\right)$. 
Residu kemudian diabukan pada suhu $550^{\circ} \mathrm{C}$ selama 2 jam, kemudian didinginkan dalam desikator dan ditimbang $\left(\mathrm{W}_{3}\right)$. Percobaan dilakukan 3 kali ulangan.

\section{Penetapan Kadar Karbohidrat}

Penetapan kadar karbohidrat contoh menggunakan metode selisih dengan persamaan berikut:

Kadar karbohidrat dapat dicerna $(\%$ bk $)=$ $100 \%$ - [kadar air (\%) + kadar lemak

$(\% \mathrm{bb})+$ kadar abu $(\% \mathrm{bb})+$ kadar protein

$(\% \mathrm{bb})+$ kadar serat kasar (\%bb)]

Analisis Asam Amino (Sumber Saraswanti Indo Genetech tidak dipublikasikan)

Sebanyak 0,1 g sampel dimasukkan ke dalam tabung ulir, lalu ditambahkan $\mathrm{HCl} 6$ $\mathrm{N}$ sebanyak $5 \mathrm{~mL}$. Larutan tersebut kemudian dipanaskan selama 22 jam pada suhu $110^{\circ} \mathrm{C}$. Hidrolisat yang diperoleh didinginkan pada suhu kamar, lalu dilarutkan dalam labu ukur menggunakan $50 \mathrm{~mL}$ akuabides, selanjutnya larutan dihomogenkan dan disaring dengan kertas saring. Setelah itu disaring lagi menggunakan saringan minisart $0.45 \mathrm{~nm}$ lalu dimasukkan ke dalam tube, selanjutnya disiapkan tube yang diisi dengan $500 \mu \mathrm{L}$ sampel yang telah disaring, $40 \mu \mathrm{L}$ alpha amino butyric acid (AABA), dan $460 \mu \mathrm{L}$ akuabides. Campuran tersebut kemudian divorteks. Deritavisasi dilakukan menggunakan mikrovial yang diisi dengan $10 \mu \mathrm{L}$ sampel atau standar dan $70 \mu \mathrm{L}$ AccQ-Flour borat, lalu divorteks, selanjutnya ditambahkan $20 \mu \mathrm{L}$ reagen flour A dan divorteks selama 10 detik. Campuran kemudian didiamkan pada suhu kamar selama 1 menit, selanjutnya dipanasakan pada suhu $55^{\circ} \mathrm{C}$ selama 10 menit. Lalu mikrovial tersebut dimasukkan ke dalam vial untuk diinjeksikan pada KCKT.

Standar asam amino dengan konsentrasi $100 \mathrm{pmol} / \mu \mathrm{L}$ dibuat dari standar induk asam amino $2500 \mathrm{pmol} / \mu \mathrm{L}$. Sebanyak 40 $\mu \mathrm{L}$ campuran standar asam amino dipipet lalu dimasukkan ke dalam tube, kemudian ditambahkan $40 \mu \mathrm{L}$ AABA dan $920 \mu \mathrm{L}$ akuabides, lalu diderivatisasi. Pembuatan larutan blanko. Sebanyak $80 \mu \mathrm{L}$ AABA dan $920 \mu \mathrm{L}$ akuabides dimasukkan ke dalam tube, kemudian diderivatisasi. Pembuatan Standar AABA. Sebanyak 10 $\mu \mathrm{L}$ standar diambil, kemudian ditambahkan $70 \mu \mathrm{L}$ AccQ-Flour Borat lalu divorteks, selanjutnya ditambahkan $20 \mu \mathrm{L}$ reagen flour A lalu divorteks dan didiamkan selama 1 menit. Standar diinkubasi selama 10 menit pada suhu $55^{\circ} \mathrm{C}$ dan disuntikkan pada KCKT.

\section{Analisis Mineral dengan SSA}

Serbuk biji jagung yang telah diabukan dilarutkan dengan $10 \mathrm{~mL} \mathrm{HNO}_{3}$ pekat, kemudian dipanaskan di atas piringan pemanas sampai larutannya berwarna jernih. Larutan ini disaring ke dalam labu takar $50 \mathrm{~mL}$ dan ditera dengan air bebas ion. Larutan ini digunakan untuk penentuan mineral $\mathrm{Ca}, \mathrm{Fe}, \mathrm{Mg}, \mathrm{K}, \mathrm{Zn}, \mathrm{Cu}$, Na, Mn dengan SSA.

Pembuatan kurva standar dilakukan dengan cara membuat larutan standar dari mineral yang akan dianalisis, yaitu $\mathrm{Na}, \mathrm{K}$, $\mathrm{Zn}, \mathrm{Ca}, \mathrm{Mn}, \mathrm{Cu}, \mathrm{Mg}$, dan Fe dari masingmasing larutan stok standar. Larutan stok standar dibuat dari garam $\mathrm{NaCl}, \mathrm{KCl}$, $\mathrm{ZnSO}_{4} .7 \mathrm{H}_{2} \mathrm{O}, \mathrm{CaSO}_{4} .2 \mathrm{H}_{2} \mathrm{O}, \mathrm{MnSO}_{4} \cdot \mathrm{H}_{2} \mathrm{O}$, $\mathrm{CuSO}_{4} . \mathrm{H}_{2} \mathrm{O}, \quad \mathrm{MgCl}_{2} .5 \mathrm{H}_{2} \mathrm{O}, \quad \mathrm{FeCl}_{3} .6 \mathrm{H}_{2} \mathrm{O}$ pada konsentrasi 500 ppm.Larutan stok ini dibuat larutan standar dengan deret konsentrasi tertentu untuk setiap mineralnya. Larutandibaca serapannya dengan alat SSA pada panjang gelombang dan lampu katoda yang sesuai untuk setiap unsurnya. Panjang gelombang yang digunakan pada masing- masing mineral berbeda, yaitu untuk $\mathrm{Na} 589.0 \mathrm{~nm}$, K 766.5 nm, Zn 213.9 nm, Ca 422.7 nm, Mn 279.5 nm, Cu 324.7 nm, Mg 285.2 nm, dan Fe $248.3 \mathrm{~nm}$.

Mineral contoh ditentukan dengan cara yang sama seperti larutan standar. Analisis unsur tersebut menggunakan oksidan berupa udara dan bahan bakar yang 
digunakan adalah asetilena $\left(\mathrm{C}_{2} \mathrm{H}_{2}\right)$. Kurva standar dibuat dengan memplotkan kurva hubungan antara konsentrasi dan absorbans larutan standar dari hasil pengukuran. Konsentrasi mineral contoh ditentukan dari kurva standar.

\section{Analisis statistika}

Analisis statistika dilakukan menggunakan metode one way annova untuk membandingkan nilai yang diperoleh dari analisis sampel jagung perlakuan nanomagnetit yang dibandingkan dengan sampel jagung tanpa perlakuan (kontrol) dan perlakuan $\mathrm{Fe}$ EDDHA. Pengujian statistik ini menggunakan perangkat lunak komputer SPSS 22.0.

\section{Hasil dan Pembahasan}

Pemilihan Sampel Jagung

Penanaman jagung dengan pemupukan nanomagnetit $\left(\mathrm{Fe}_{3} \mathrm{O}_{4}\right)$ dan Fe-kelat masing-masing diaplikasikan dengan variasi konsentrasi, yaitu 25 ppm, 125 ppm dan $250 \mathrm{ppm}$. Pemberian pupuk dilakukan dengan cara menuangkan $50 \mathrm{~mL}$ larutan pada tanah secara melingkar dengan jarak $5 \mathrm{~cm}$ dari pangkal batang. Pemberian pupuk dilakukan sebanyak 4 kali, dengan interval tiap 7 hari. Penerapan dilakukan pada tanaman jagung dengan 6 replikat pada tiap perlakuan. Hasil pertumbuhan tanaman jagung terbaik yang diperoleh adalah dengan penambahan nanomagnetit pada konsentrasi 25 ppm, sedangkan Fekelat pada konsentrasi 250 ppm. Sebagai kontrol digunakan sampel jagung yang diperoleh dari penanaman jagung yang dilakukan di kebun percobaan Sarana Diseminasi Fakultas Pertanian IPB Dramaga. Varietas jagung yang digunakan adalah jagung manis hibrida (merk Jawara) dengan usia panen tiga bulan yang ditanam pada tanah dengan $\mathrm{pH} 5.96$ (masam), kadar C organik $4.95 \%$ (sedang), dan kadar $\mathrm{Fe} 7.11 \%$ (sedang) (Balitro 2017). Sehingga sampel yang digunakan untuk pengujian pada penelitian ini adalah jagung hasil pemupukan oleh nanomagnetit $25 \mathrm{ppm}$ dan Fe-kelat 250 ppm, serta jagung tanpa perlakuan sebagai kontrol (Gambar 1).

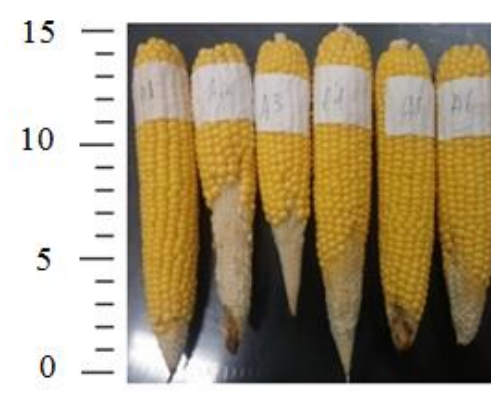

$\mathrm{cm}$

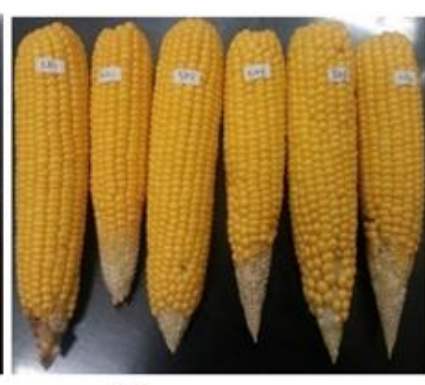

(b)

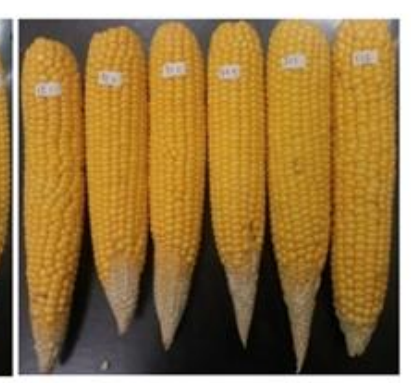

(c)

Gambar 1. Jagung tanpa perlakuan (a), perlakuan nanomagnetit 25 ppm (b), dan perlakuan Fe-kelat 250 ppm (c)

\section{Kandungan Proksimat pada Biji Jagung}

Analisis proksimat yang dilakukan pada penelitian ini meliputi kadar air, abu, lemak, serat, protein, serta karbohidrat. Hasil penelitian menunjukkan penambahan unsur hara Fe meningkatkan kadar abu, protein, serta karbohidrat, sedangkan kadar air, serat, dan lemak menurun seperti ditunjukkan pada Gambar
2. Menurut Nair et al. (2010) efek bidang elektromagnetit pada nanomagnetit mempengaruhi tingkat transpor ion pada tanaman sehingga dapat meningkatkan pertumbuhan tanaman, memengaruhi komposisi kimia pada tanaman dan aktivitas enzim yang terlibat dalam perkembangan tanaman. 


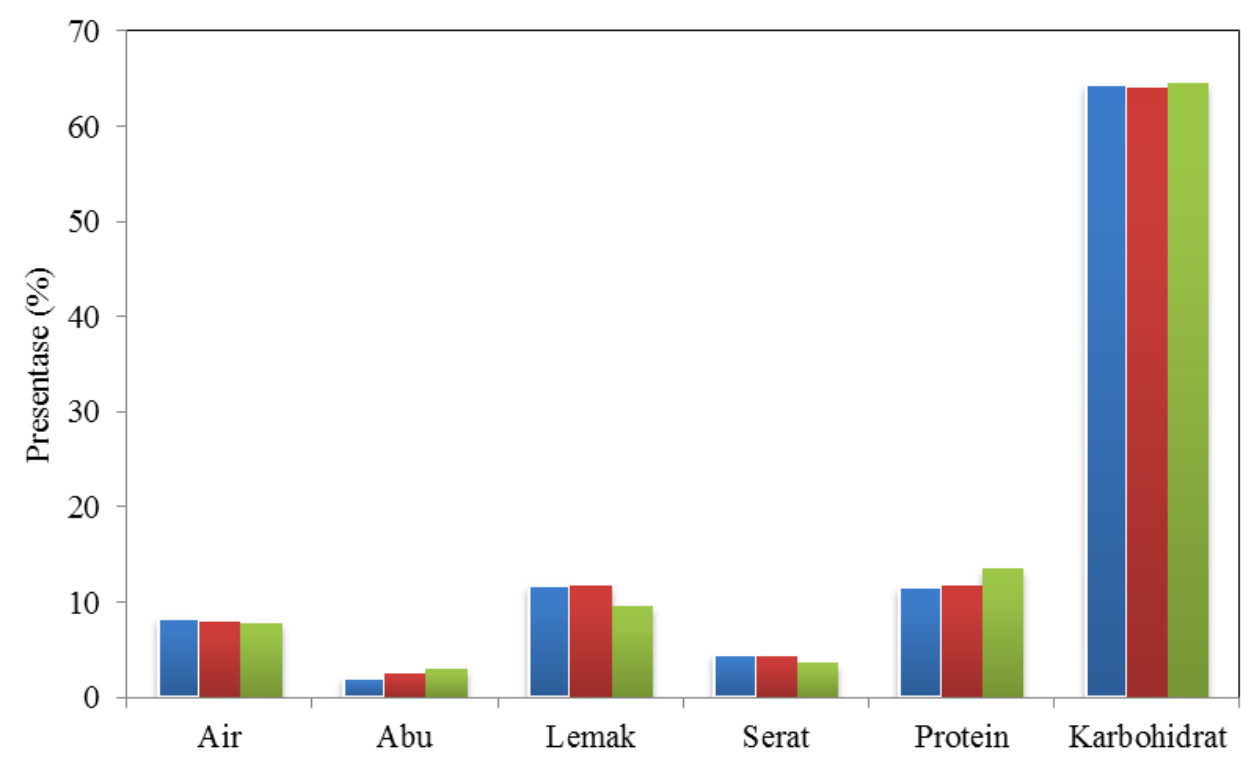

Gambar 2. Pengaruh perlakuan penambahan unsur hara besi terhadap kadar proksimat pada biji jagung

Ketiga sampel jagung memiliki besar kadar air yang dapat dikategorikan baik karena memiliki nilai kadar air pada sampel kering berada dibawah $10 \%$. Kadar air digunakan untuk mengetahui daya simpan suatu bahan dapat diketahui. Kadar abu dari suatu bahan menunjukkan total mineral yang terkandung dalam bahan tersebut (Andarwulan et al. 2006). Kadar abu selanjutnya dilakukan analisis untuk mengetahui kandungan mineral secara spesifik. Kadar lemak dalam sampel biji jagung melalui metode ekstraksi soklet. Lemak diekstraksi menggunakan bahan pelarut non-polar yaitu heksana, pelarut secara berkala akan merendam sampel dan mengekstrak lemak atau minyak (AOAC 1999).

Analisis kadar protein menggunakan metode Kjeldahl didasarkan pada pengukuran kadar nitrogen total yang ada di dalam contoh. Terdapat tahap pada analisis kjeldahl, yaitu tahap penghancuran (digestion), tahap netralisasi dan disitilasi, dan tahap titrasi. Kandungan nitrogen pada perlakuan nanomagnetit meningkat diduga karena medan elektromagnetik yang memodifikasi laju pengangkutan ion melintasi membran plasma atau mempengaruhi struktur dinamika protein lipida membran sel, sehingga dapat menyebabkan perubahan permeabilitas membran plasma (Stange et al. 2002).

Kandungan karbohidrat ditentukan sebagai karbohidrat total by difference, artinya kandungan tersebut dapat diperoleh dari pengurangan angka 100 dengan presentase komponen lain (air, abu, lemak, dan protein). Bila hasil pengurangan tersebut dikurangi dengan presentase serat maka akan diperoleh kadar karbohidrat yang dapat dicerna (Nielsen 2003).

Analisis data kadar proksimat dilakukan dengan menggunakan uji anova satu arah. Uji homogenitas varian dilakukan untuk memastikan bahwa perbedaan yang terdapat pada hasil pengujian terjadi bukan karena data dasar, melainkan karena perlakuan. Pada Tabel 1 menunjukan hasil uji anova bahwa kadar abu, lemak, serat, dan protein berbeda secara signifikan, sedangkan pada uji karbohidrat tidak berbeda signifikan. Maka dilakukan uji least significant difference (LSD) untuk mengetahui besarnya perbedaan setiap perlakuan. Pada Tabel 2 hasil uji LSD menunjukan baik kontrol maupun perlakuan nanomagnetit dan perlakuan Fe-kelat 
Tabel 1. Persentase kadar proksimat setiap perlakuan dan analisis varian dari kombinasi kadar proksimat biji jagung untuk uji $F$

\begin{tabular}{ccccccc}
\hline \multirow{2}{*}{ Proksimat } & $\mathrm{A}$ & $\mathrm{N}$ & $\mathrm{K}$ & \multicolumn{3}{c}{ Uji $F$} \\
\cline { 6 - 7 } & $(\%)$ & $(\%)$ & $(\%)$ & $F_{\text {hitung }}$ & $F_{\text {tabel }}$ & Simpulan \\
\hline Air & $8.29 \pm 0.03$ & $7.91 \pm 0.04$ & $7.86 \pm 0.05$ & - & - & - \\
Abu & $2.08 \pm 0.10$ & $2.56 \pm 0.16$ & $3.01 \pm 0.13$ & 35.0970 & 5.1433 & Beda \\
Lemak & $11.74 \pm 0.14$ & $11.74 \pm 0.01$ & $9.54 \pm 0.21$ & 218.1640 & 5.1433 & Beda \\
Serat & $4.55 \pm 0.14$ & $4.28 \pm 0.10$ & $3.70 \pm 0.13$ & 36.0090 & 5.1433 & Beda \\
Protein & $11.53 \pm 0.07$ & $11.74 \pm 0.02$ & $13.52 \pm 06$ & 1072.51 & 5.1433 & Beda \\
Karbohidrat & $61.83 \pm 0.18$ & $61.76 \pm 0.23$ & $62.83 \pm 0.38$ & 4.9700 & 5.1433 & Sama \\
\hline
\end{tabular}

Keterangan: $\mathrm{A}=$ tanpa perlakuan, $\mathrm{N}=$ perlakuan nanomagnetit, dan $\mathrm{K}=$ perlakuan $\mathrm{Fe}-$ kelat

Jika $F_{\text {hitung }}>F_{\text {tabel }}$ maka,Ho ditolak

Jika $F_{\text {hitung }}<F_{\text {tabel }}$ maka, Ho diterima

Tabel 2. Perbandingan keseluruhan (multiple comparison) kadar proksimat biji jagung dengan uji LSD (Least Significant Difference)

\begin{tabular}{cccccc}
\hline \multirow{2}{*}{ J $)$} & $(\mathrm{J})$ & \multicolumn{4}{c}{ Signifikansi } \\
\cline { 3 - 6 } Jagung & Jagung & Abu & Lemak & Serat & Protein \\
\hline $\mathrm{A}$ & $\mathrm{N}$ & 0.005 & $0.987^{*}$ & 0.041 & 0.004 \\
$\mathrm{~A}$ & $\mathrm{~K}$ & 0.000 & 0.000 & 0.000 & 0.000 \\
$\mathrm{~N}$ & $\mathrm{~K}$ & 0.007 & 0.000 & 0.001 & 0.000
\end{tabular}

Keterangan: $\mathrm{A}=$ tanpa perlakuan, $\mathrm{N}=$ perlakuan nanomagnetit, dan $\mathrm{K}=$ perlakuan $\mathrm{Fe}-$ kelat

*) tidak berbeda signifikan

Jika signifikansi $>0.05$, maka Ho diterima

Jika signifikansi $<0.05$, maka Ho ditolak

Kandungan Asam Amino pada Biji Jagung

Analisis asam amio penting untuk dilakukan untuk mengetahui kualitas protein suatu bahan pangan tertentu (Elfita 2014). Penentuan kadar asam amino dilakukan dengan menggunakan ultra high performance liquid chromatography (UPLC) dari merk waters. UPLC adalah teknologi terbaru dari HPLC atau KCKT, kelebihan UPLC dibandingkan HPLC adalah lebih sensitif, kolom yang digunakan lebih kecil, dan sampel yang digunakan untuk analisis relatif sedikit. Fase diam yang digunakan adalah kolom ACCQ-Tag Ultra C18 dengan fase geraknya eluent A (merk waters). Sistem fase gerak yang digunakan adalah elusi gradien. Elusi gradien, yaitu fase gerak dengan komposisi yang berubah selama masa analisis. Keuntungan menggunakan elusi gradien adalah waktu analisis lebih 
cepat, ketajaman peak bertambah, dan resolusi yang cukup baik. Sebelum dianalisis, sampel terlebih dahulu dihidrolisis.

Hidrolisis berfungsi menguraikan protein secara sempurna menjadi asam amino bebas. Hidrolisis protein menjadi asam amino dapat menggunakan asam, alkali, ataupun enzim. Pada penentuan ini, hidrolisis menggunakan asam klorida pada konsentrasi $6 \mathrm{~N}$, selama 22 jam pada suhu $110^{\circ} \mathrm{C}$. Hidrolisat yang diperoleh kemudian diencerkan dan disaring dengan penyaring $0.45 \mu \mathrm{m}$. Penyaringan hidrolisat bertujuan agar kolom tidak tersumbat dan analisis dapat berjalan dengan baik. Standar yang digunakan adalah multi standar AABA.

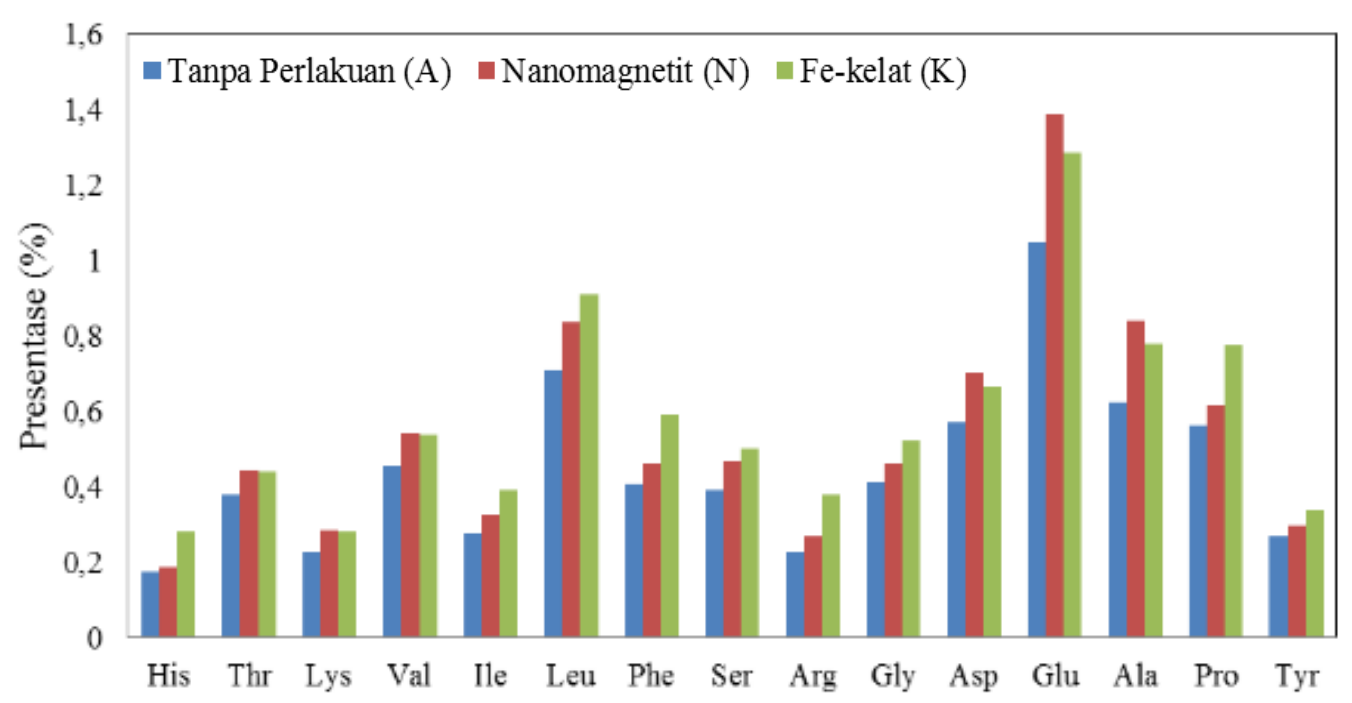

Gambar 3. Pengaruh berbagai perlakuan penambahan unsur hara besi terhadap kadar asam amino pada biji jagung

Hasil pengujian asam amino menggunakan UPLC menunjukkan bahwa perlakuan Fe meningkatkan semua jenis asam amino dibandingkan dengan kontrol (Gambar 3). Terdapat tujuh komponen asam amino essensial dan delapan asam amino non essensial yang diuji dalam penelitian. Asam amino essensial diantaranya histidina, treonina, lisina, valina, isoleusina, leusina, dan fenilalanina. Hasil menunjukkan total asam amino essensial pada kontrol sebesar $2.64 \%$, perlakuan nanomagnetit $3.10 \%$, dan perlakuan Fe-kelat 3.43\% (Tabel 3). Persen kenaikan konsetrasi asam amino essensial pada perlakuan nanomagnetit dibandingkan dengan kontrol sebesar ratarata $16.87 \%$, sedangkan pada perlakuan Fe-kelat meningkat rata-rata $33.14 \%$ terhadap kontrol.
Asam amino non essensial yang ditentukan, yaitu serina, arginina, glisina, asam aspartat, alanina, prolina, dan tirosina. Hasil menunjukkan asam amino non essensial pada kontrol sebesar $4.10 \%$, perlakuan nanomagnetit $5.05 \%$, dan perlakuan Fe-kelat $5.26 \%$. Persen kenaikan konsetrasi asam amino non essensial pada perlakuan nanomagnetit sebesar rata-rata $19.72 \%$, sedangkan pada perlakuan Fe-kelat meningkat rata-rata $30.99 \%$.

Peningkatan asam amino disebabkan karena nanopartikel memiliki sifat fisikokimia yang unik dan potensi untuk meningkatkan metabolisme tanaman yang mempengaruhi peningkatan biosintesis asam amino (Giraldo et al., 2014). Perlakuan Fe-kelat meningkatkan total kadar asam amino sebesar $6.62 \%$ dibandingkan dengan sampel perlakuan 
nanomagnetit. Hal tersebut disebabkan karena Fe-kelat tidak hanya menyumbang unsur besi, tetapi juga menyumbangkan unsur nitrogen sehingga memengaruhi metabolisme protein dan asam aminonya.

\section{Kandungan Mineral pada Biji Jagung}

Analisis mineral ditentukan menggunakan sampel biji jagung yang telah diabukan. Abu merupakan residu anorganik yang diperoleh dari pengabuan atau pemanasan pada suhu tinggi $>450^{\circ} \mathrm{C}$. Abu yang diperoleh kemudian dilarutkan dengan asam pekat, kemudian dipanaskan hingga diperoleh larutan brwarna jernih. Asam kuat yang digunakan pada penelitian adalah $\mathrm{HNO}_{3}$. Analisis kadar mineral dalam abu dapat dilakukan dengan metode spektrofotometri serapan atom (SSA). Instrumen SSA memiliki sensitivitas pengukuran mineral yang tinggi, yaitu hingga satuan part per million (ppm).

Tabel 3. Presentase kenaikan kadar asam amino pada biji jagung karena penambahan unsur hara besi

\begin{tabular}{|c|c|c|c|c|c|c|}
\hline \multirow{2}{*}{\multicolumn{2}{|c|}{ Asam Amino }} & \multirow{2}{*}{$\begin{array}{c}\text { A } \\
(\%)\end{array}$} & \multirow{2}{*}{$\begin{array}{l}\mathrm{N} \\
(\%)\end{array}$} & \multirow{2}{*}{$\begin{array}{c}\mathrm{K} \\
(\%)\end{array}$} & \multicolumn{2}{|c|}{$\begin{array}{c}\text { Persen kenaikan } \\
\text { konsentrasi }\end{array}$} \\
\hline & & & & & $\begin{array}{c}\mathrm{N} \text { terhadap } \\
\mathrm{A}\end{array}$ & $\begin{array}{c}\text { K terhadap } \\
\text { A }\end{array}$ \\
\hline \multirow{8}{*}{ Essensial } & Histidina & 0.17 & 0.19 & 0.28 & 7.43 & 59.86 \\
\hline & Treonina & 0.38 & 0.45 & 0.44 & 16.79 & 15.24 \\
\hline & Lisina & 0.23 & 0.29 & 0.28 & 25.9 & 23.71 \\
\hline & Valina & 0.46 & 0.54 & 0.54 & 18.85 & 19.00 \\
\hline & Isoleusina & 0.28 & 0.33 & 0.39 & 17.73 & 41.11 \\
\hline & Leusina & 0.71 & 0.84 & 0.91 & 18.18 & 28.43 \\
\hline & Fenilalanina & 0.41 & 0.46 & 0.59 & 13.26 & 44.67 \\
\hline & Total & 2.64 & 3.10 & 3.43 & 17.42 & 29.92 \\
\hline \multirow{9}{*}{$\begin{array}{c}\text { Non } \\
\text { essensial }\end{array}$} & Serina & 0.39 & 0.47 & 0.50 & 19.38 & 27.48 \\
\hline & Arginina & 0.23 & 0.27 & 0.38 & 17.65 & 65.06 \\
\hline & Glisina & 0.41 & 0.46 & 0.52 & 12.43 & 25.78 \\
\hline & Asam Aspartat & 0.57 & 0.70 & 0.67 & 22.23 & 16.58 \\
\hline & Asam Glutamat & 1.05 & 1.39 & 1.29 & 32.00 & 22.41 \\
\hline & Alanina & 0.62 & 0.84 & 0.78 & 34.67 & 24.69 \\
\hline & Prolina & 0.56 & 0.62 & 0.78 & 9.48 & 38.08 \\
\hline & Tirosina & 0.27 & 0.30 & 0.34 & 9.99 & 27.87 \\
\hline & Total & 4.10 & 5.05 & 5.26 & 23.17 & 28.29 \\
\hline
\end{tabular}

Keterangan : $\mathrm{A}=$ tanpa perlakuan, $\mathrm{N}=$ perlakuan nanomagnetit, $\mathrm{K}=$ perlakuan Fe-kelat

Peningkatan asam amino disebabkan karena nanopartikel memiliki sifat fisikokimia yang unik dan potensi untuk meningkatkan metabolisme tanaman yang mempengaruhi peningkatan biosintesis asam amino (Giraldo et al., 2014). Perlakuan Fe-kelat meningkatkan total kadar asam amino sebesar $6.62 \%$ dibandingkan dengan sampel perlakuan nanomagnetit. Hal tersebut disebabkan karena Fe-kelat tidak hanya menyumbang unsur besi, tetapi juga menyumbangkan unsur nitrogen sehingga memengaruhi metabolisme protein dan asam aminonya.

\section{Kandungan Mineral pada Biji Jagung}

Analisis mineral ditentukan menggunakan sampel biji jagung yang telah diabukan. Abu merupakan residu anorganik yang diperoleh dari pengabuan atau pemanasan pada suhu tinggi $>450^{\circ} \mathrm{C}$. Abu yang diperoleh kemudian dilarutkan 
dengan asam pekat, kemudian dipanaskan hingga diperoleh larutan brwarna jernih. Asam kuat yang digunakan pada penelitian adalah $\mathrm{HNO}_{3}$. Analisis kadar mineral dalam abu dapat dilakukan dengan metode spektrofotometri serapan atom (SSA). Instrumen SSA memiliki sensitivitas pengukuran mineral yang tinggi, yaitu hingga satuan part per million ( $\mathrm{ppm}$ ).

Terdapat delapan mineral yang diuji pada penelitian ini, yaitu $\mathrm{Mn}, \mathrm{Zn}, \mathrm{Na}, \mathrm{Mg}$, $\mathrm{K}, \mathrm{Ca}, \mathrm{Fe}$, dan $\mathrm{Cu}$. Mineral-mineral tersebut umum dijumpai pada bahan jagung (USDA 2016). Perlakuan penambahan nanomagnetit dan Fe-kelat pada tanaman jagung meningkatkan hampir semua kandungan mineral pada bji jagung seperti ditunjukkan Gambar 4. Kandungan $\mathrm{Fe}$ pada perlakuan nanomagnetit meningkat $14.28 \%$ dan pada perlakuan Fe-EDDHA meningkat $86.33 \%$ dibandingkan kontrol. Menurut penelitian yang telah dilakukan oleh Jalali (2016) pemberian $\mathrm{Fe}$ nanomagnetit dan $\mathrm{Fe}$ EDDHA pada tanaman jagung pada tingkat pertumbuhan vegetatif dan generatif meningkatkan kandungan total protein, $\mathrm{Fe}, \mathrm{Fe}^{2+}$, dan $\mathrm{Ca}$ pada daun dibandingkan dengan kontrol, hal tersebut tersebut dapat dikaitkan dengan keseimbangan redoks pada tanaman.

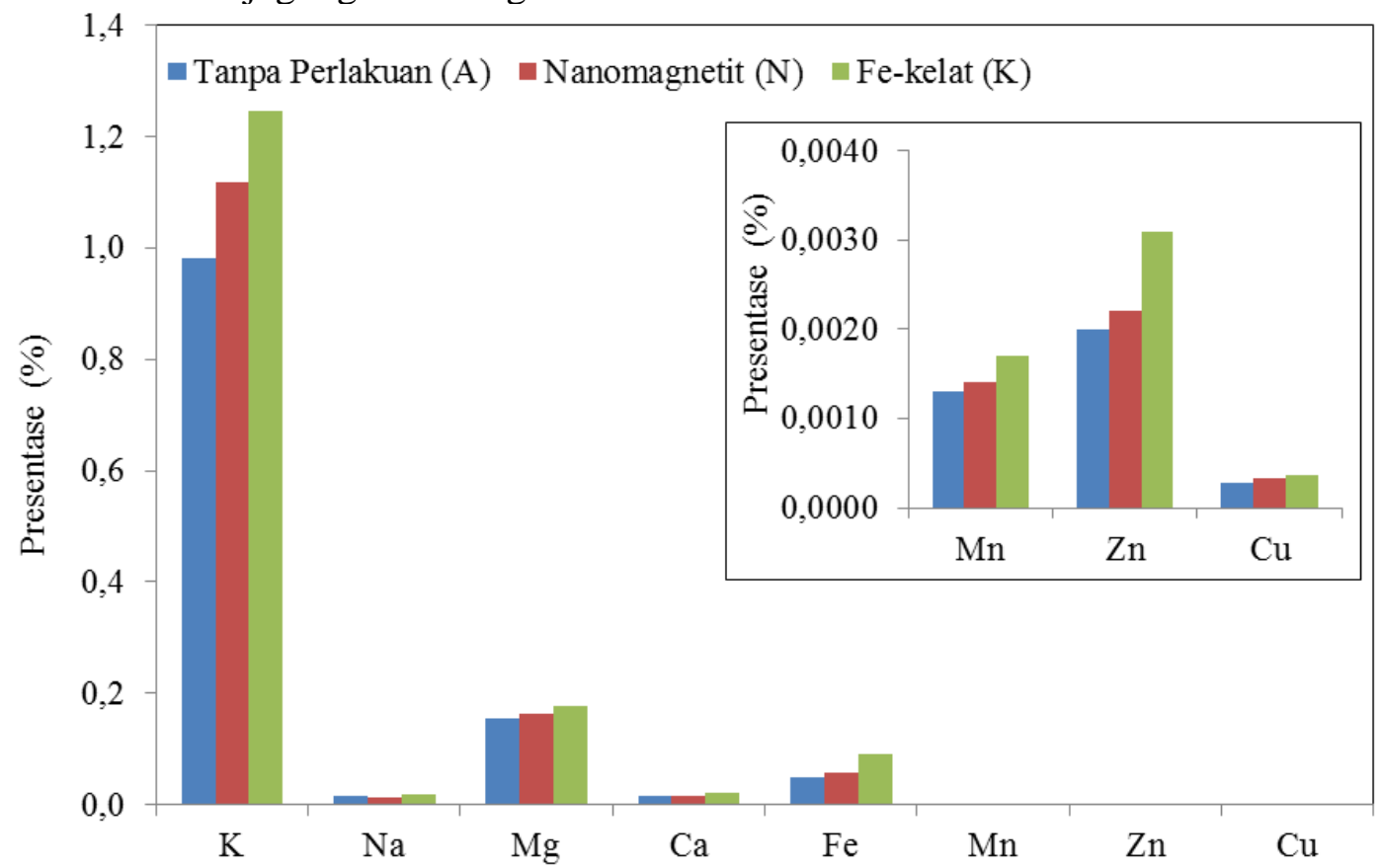

Gambar 4. Pengaruh perlakuan penambahan unsur hara besi terhadap kadar asam amino pada biji jagung

Total konsentrasi mineral pada perlakuan kontrol sebesar $1.22 \%$, perlakuan nanomagnetit $1.38 \%$, dan perlakuan Fe-EDDHA sebesar $1.56 \%$. Perlakuan Fe-EDDHA pada tanaman jagung meningkatkan total kadar mineral lebih tinggi dibandingkan dengan perlakuan nanomagnetit. Hal tersebut terjadi karena kelat EDDHA berfungsi untuk menstabilkan $\mathrm{Fe}$ pada tumbuhan. Sifat dari kelat adalah mudah larut dalam air, sehingga sangat mudah untuk masuk melalui ruang antar sel pada tumbuhan, berbeda dengan nanomagnetit yang akan terdispersi di dalam air dan tidak dapat larut dalam air. Meskipun ukuranya nano, namun ukuran partikel yang sangat kecil juga dapat memicu terjadinya aglomerasi (Du dan Liu 2006). Efek yang ditimbulkan oleh nanopartikel tersebut bergantung pada komposisi, kensentrasi, dan ukuran (Siddiqui et al. 2015). 
Pengolahan data kadar mineral menggunakan uji anova satu arah diperoleh hasil sebagai berikut, uji homogenitas menunjukkan nilai signifikansi pada kadar mineral biji jagung lebih dari 0.5 , sehingga dapat diartikan ketiga varian dari ketiga variabel adalah sama. Uji anova pada sampel biji jagung menunjukkan kadar mineral $\mathrm{Mn}, \mathrm{Zn}, \mathrm{Mg}$, $\mathrm{K}$, $\mathrm{Ca}$, dan $\mathrm{Fe}$ berbeda signifikan, sedangkan mineral $\mathrm{Na}$ dan $\mathrm{Cu}$ tidak berbeda secara signifikan (Tabel 4). Hal tersebut dapat disebabkan oleh perbedaan penyerapan hara pada tanaman.

Faktor yang memengaruhi penyerapan hara dalam tanaman diantaranya adalah sifat fisikokimia ion dan interaksi antar ion. Berdasarkan sifat fisikokimianya, ion dengan valensi sama, laju penyerapannya berkorelasi negatif dengan jari-jari ion. Laju penyerapan semakin menurun dengan semakin tinggi muatannya, karena muatan yang lebih tinggi menyebabkan interaksinya dengan muatan membran meningkat, artinya laju penyerapan molekul tak bermuatan $>>$ kation $^{(+)} /$anion $^{(-}$ ) > kation ${ }^{(2+)} /$ anion $^{(2+)}$ (Wiraatmaja 2016).

Dari hasil uji tarik diperoleh data nilai tegangan pada setiap variasi konsentrasi $\mathrm{TiO}_{2}$. Tegangan atau kuat tarik didefinisikan sebagai perbandingan antara gaya yang bekerja pada benda dengan luas penampang benda (Baker, 2004). Pada gambar 3, diperoleh nilai tegangan maksimal sebesar $502,739 \mathrm{kN} / \mathrm{m}^{2}$ terdapat pada variasi konsentrasi $\mathrm{TiO}_{2} 0,25 \%$.

Tabel 4. Persentase kadar mineral setiap perlakuan dan analisis varian dari kombinasi kadar proksimat biji jagung untuk uji $F$

\begin{tabular}{ccccccc}
\hline \multirow{2}{*}{ Mineral } & $\mathrm{A}$ & $\mathrm{N}$ & $\mathrm{K}$ & & $\mathrm{Uji} F$ & \\
\cline { 7 - 7 } & $(\%)$ & $(\%)$ & $(\%)$ & \multicolumn{1}{c}{$F_{\text {hitung }}$} & $F_{\text {tabel }}$ & Simpulan \\
\hline $\mathrm{Mn}$ & 0.0013 & 0.0014 & 0.0017 & 101.5500 & 5.1433 & Beda \\
$\mathrm{Zn}$ & 0.0020 & 0.0022 & 0.0031 & 745.9300 & 5.1433 & Beda \\
$\mathrm{Na}$ & 0.0154 & 0.0131 & 0.0173 & 2.8500 & 5.1433 & Sama \\
$\mathrm{Mg}$ & 0.1563 & 0.1640 & 0.1763 & 47.8940 & 5.1433 & Beda \\
$\mathrm{K}$ & 0.9817 & 1.1173 & 1.2462 & 7.6500 & 5.1433 & Beda \\
$\mathrm{Ca}$ & 0.0154 & 0.0161 & 0.0224 & 39.4810 & 5.1433 & Beda \\
$\mathrm{Fe}$ & 0.0495 & 0.0566 & 0.0923 & 136.2600 & 5.1433 & Beda \\
$\mathrm{Cu}$ & 0.00028 & 0.00033 & 0.00037 & 1.2040 & 5.1433 & Sama
\end{tabular}

Keterangan: $\mathrm{A}=$ tanpa perlakuan, $\mathrm{N}=$ perlakuan nanomagnetit, dan $\mathrm{K}=$ perlakuan $\mathrm{Fe}$ kelat

Jika $F_{\text {hitung }}>F_{\text {tabel }}$ maka,Ho ditolak

Jika $F_{\text {hitung }}<F_{\text {tabel }}$ maka, Ho diterima 
Tabel 5 Perbandingan keseluruhan (multiple comparison) kadar mineral jagung dengan uji LSD (Least Significant Difference)

\begin{tabular}{cccccccc}
\hline \multirow{2}{*}{$\begin{array}{c}\text { I }) \\
\text { Jagung }\end{array}$} & Jagung & Mn & $\mathrm{Zn}$ & $\mathrm{Mg}$ & $\mathrm{K}$ & $\mathrm{Ca}$ & $\mathrm{Fe}$ \\
\cline { 3 - 8 } & $\mathrm{N}$ & 0.0140 & 0.0000 & 0.0100 & 0.0920 & $0.4360^{*}$ & 0.0440 \\
$\mathrm{~A}$ & $\mathrm{~K}$ & 0.0000 & 0.0000 & 0.0100 & 0.0080 & 0.0000 & 0.0000 \\
$\mathrm{~A}$ & $\mathrm{~K}$ & 0.0000 & 0.0000 & 0.0100 & $0.1050^{*}$ & 0.0000 & 0.0000 \\
$\mathrm{~N}$ & & & & & & &
\end{tabular}

Keterangan: $\mathrm{A}=$ tanpa perlakuan, $\mathrm{N}=$ perlakuan nanomagnetit, dan $\mathrm{K}=$ perlakuan $\mathrm{Fe}-$ kelat

*) tidak berbeda signifikan

Jika signifikansi $>0.05$, maka Ho diterima

Jika signifikansi $<0.05$, maka Ho ditolak

Perbandingan keseluruhan mineral pada sampel biji jagung dengan uji LSD menunjukkan hampir semua kelompok perlakuan berbeda, nilai signifikansinya kurang dari 0.05 , kecuali mineral kalium pada sampel perlakuan nanomagnetit dibandingkan dengan Fe-kelat dan kontrol yang menunjukkan nilai signifikansi yang lebih besar 0.05 . Hal tersebut juga terjadi pada kadar kalsium sampel biji jagung yang menunjukan tidak berbeda signifikan pada perlakuan kontrol dan nanomagnetit (Tabel 5)

\section{Kesimpulan}

Penambahan pupuk nanomagnetit 25 ppm dibandingkan dengan pupuk komersial Fe-kelat (EDDHA) 250 ppm diperoleh hasil sebagai berikut, penambahan pupuk nanomagnetit meningkatkan kadar proksimat (abu dan protein), total asam amino, dan total mineral pada biji jagung, meskipun presentase peningkatannya lebih rendah dibandingkan dengan perlakuan Fe kelat. Hasil menunjukkan perlakuan nanomagnetit meningkatkan kadar abu dan protein sebesar $23.07 \%$ dan $1.82 \%$. Serta meningkatkan kandungan total asam amino dan total mineral pada biji jagung sebesar $18.40 \%$ dan $28.93 \%$ terhadap kontrol.

Phy and Biochem. (49):471-482. doi: 10.1016/j.plaphy.

Andarwulan N, Kusnandar F, Herawati D. 2006. Analisis Abu dan Mineral. Modul Kuliah Analisis Pangan. Departemen Ilmu dan Teknologi Pangan IPB. Bogor (ID): IPB Press.

Bozorgi HR. 2012. Effects of foliar spraying with marine plant Ascophyllum nodosum extract and nano iron chelate fertilizer on fruit yield and several attributes of 
eggplant (Solanum melongena). $J$. Agr Bio Sci. 7(5):357-362.

Du J, Liu H. 2006. Preparation of superparamagnetic $\quad \gamma-\mathrm{Fe}_{2} \mathrm{O}_{3}$ nanoparticles in nonaqueous medium by $\gamma$-irradiation. J. Magn Magn Mat. 302(1): 263-266.

Elfita L. 2014. Analisis profil protein dan asam amino sarang burung walet (Collocalia Fuchiphaga) asal Painan. J. Farm. 4(1):61-69. ISSN :1978-8193

El-Nasr A, El-Hennawy HM, El-Kereamy AMH, El-Yazied A, Eldin AT. 2015. Effect of magnetite nanoparticles $\left(\mathrm{Fe}_{3} \mathrm{O}_{4}\right)$ as nutritive supplement on pear saplings. Mid Eas Jurnal App Sci. 5(3): 777-785.

Giraldo J, Landry M, Faltermeier S, Nicholas M, Iverson N, Boghossian A, Reuel N, Hilmer A, Sen F, Brew J, Stran M. 2014. Plant nanobionics approach to augment photosynthesis and biochemical sensing. Nat Mater. 13:400-408.

Jalali M, Faezah G, Ali Muhammad MS. 2016. Effect of $\mathrm{Fe}_{3} \mathrm{O}_{4}$ nanoparticles and iron chelats on the antioxidant capacity and nutritional value of soil cultivated maize (Zea mays) plants. J. compilation Corp and Pasture science. 6(7):621-628.

Nair R, Varghese H, Nair B, Maekawa T, Yoshida Y, Kumar D. 2010. Nanoparticulate material delivery to plants. Plant Sci. 179:154-163.

Nielsen S. 2003. Food analysis $3^{r d}$. New York (US):Kluwer Academic Plenum publisher.

Oh, S.-H., Cho, S.-W., Kwon, T.-H., Yang, M.-S. 1996. Purification and characterization of phytoferritin. Jurnal Biochem. Mol. Biol. 29:540 544.

Prahasta. 2009. Agribisnis Jagung. Bandung (ID):Pustaka Grafika.

Randabunga R. 2018. Nanomagnetit Berbasis Asam Askorbat untuk
Memacu Suplai Hara $\mathrm{Fe}$ dan Pertumbuhan Jagung. [skripsi]. Institut Pertanian Bogor.

Siddiqui MH, Al-Whaibi MH, Firoz M, Al-Khaishany MY. 2015. Role of Nanotechnology and Plant Sciences. Switzerland $(\mathrm{CH})$ :Springer Cham.

Stange BC, Rowland RE, Rapley BI, Podd JV. 2002. ELF magnetic fields increase amino acid uptakeinto Vicia faba L. roots and alter ion movement across the plasma membrane. Bioelectromagnetics. 23(1):347354.

[USDA] United State Departemen of Agricultural. 2016. National Nutrient Database for Standard Reference. 2016. ndb.nal.usda.gov.

Wiraatmaja I. 2016. Pergerakan Hara Mineral dalam Tanaman. [Internet]. [diunduh 2018 September 02]. Tersedia pada https://www.google.co.id/url?sa=t\& source=web\&rct=j\&url=https://sim dos.unud.ac.id/uploads/file_pendidi kan_1_dir/cab302690a210a3fcb6f8f 38e4f68a20.pdf\&ved=2ahUKEwjz4 P8pzdAhG5o8KHVw7AFMQFjAC egQ1BxAB\&usg=AOvVaw2TK8nY 7p89A9jAARtZjbQz 